\title{
Ultrastructural aspects of lymphoreticular cells in rheumatoid synovium
}

\author{
T. NEUMARK AND K. FARKAS \\ National Institute of Rheumatism and Physiotherapy, Budapest, Hungary
}

The ultrastructural aspects of the lymphoid and plasma cell infiltrate in rheumatoid synovium have received little attention. We have therefore undertaken a study of the germinal follicles in rheumatoid synovium, and here draw attention to:

(a) Cytoplasmic bridging between lymphocytes, plasma cells, and phagocytes;

(b) Cytoplasmic and nuclear inclusions in lymphocytes;

(c) Detachment of cytoplasmic fragments from various morphological types of cell in germinal follicle.

\section{Material and methods}

Synovial tissue was obtained from 65 patients with rheumatoid arthritis during synovectomy of the knee. The patients had either definite or classical disease by the ARA criteria (Ropes, Bennett, Cobb, Jacox, and Jesssar, 1959). For electron microscopy, small tissue blocks were fixed in Karnovsky fluid and postfixed in buffered osmium tetroxide, dehydrated in graded ethanol, and embedded in Durcupan ACM. Sections cut with a Reichert OM-2 ultratome were stained with uranyl acetate and lead citrate and examined with a Tesla BS 513A electron microscope. Five Blocks were prepared from the biopsy from each patient, and five grids of each block were investigated.

\section{Results}

Various stages in the maturation of plasma cells were seen in the germinal follicles. Cells resembling proplasmatocytes (Fig. 1) contained rough-surfaced endoplasmic reticulum, either tubular or less frequently with dilated cisternae; in the latter electron dense fibrogranular substances or Russell bodies occurred. Ribosomes in these cells sometimes formed linear or rosette-like aggregates (Fig. 2). In the vicinity of these polysomal aggregates microtubules about $200 \AA$ in diameter and fibrogranular substance were seen (Fig. 3).

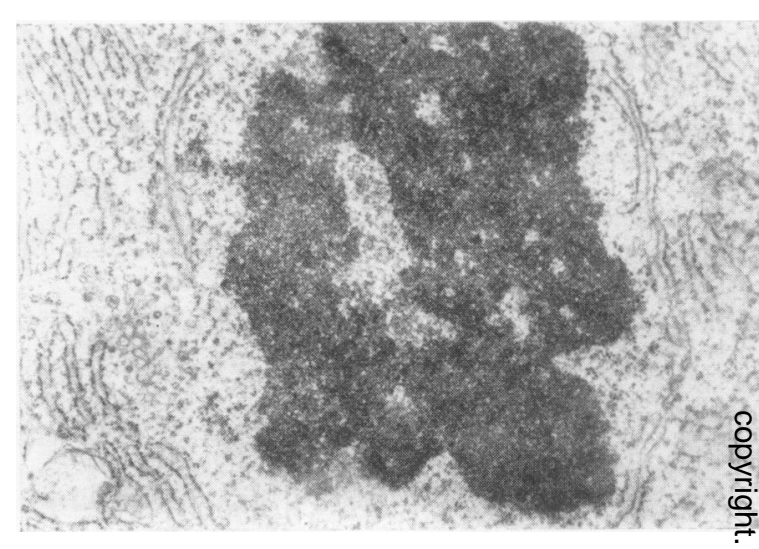

FIG. 1 Mitosis in immature plasma cell. $\times 12,000$

A striking feature of immature plasma cells and lymphocytes was the detachment from the cell surface of cytoplasmic fragments about $0.1-0.4 \mu \mathrm{m}$ in diameter. These fragments were limited by a unit membrane and contained free ribosomes, tubulofilamentous threads, vesicles filled with fibrogranular substance of varying electron density (Fig. 4), and structures resembling mature virions (Fig. 5). Enveloped virus-like particles in the extracellular space and virus-like particles budding from plasma membranes of lymphocytes and macrophages of about $1,200-1,500 \AA$ in diameter were also demonstrated in the germinal follicles (Fig. 6).

In lymphocytes, nuclear and cytoplasmic inclusions were seen. In the nucleus some inclusions contained fibrillar substances and nucleocapsid-like tubular threads about $160 \AA$ in diameter showing crossstriations (Fig. 7). Others took the form of vacuoles containing fibrogranular substance. The vacuoles occurring in the cytoplasm were surrounded by ribosomes, and lacked a well-defined outer limiting membrane. Similar vacuoles were seen in the extracellular space where they were subject to phagocytosis, mainly by polymorphonuclear leucocytes 


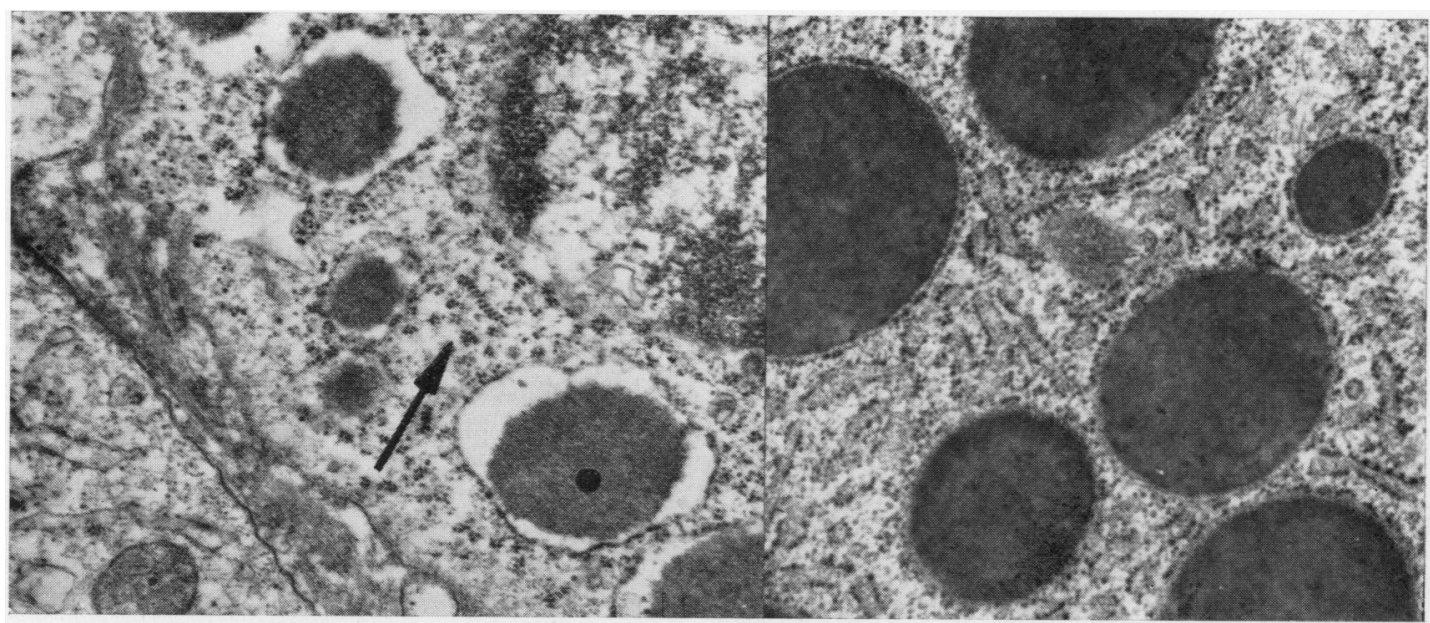

FIG. 2 (a) Detail of young plasma cell. Electron dense fibrillar substance in pronouncedly dilated, rough-surfaced endoplasmic reticulum. Linear and rosette-like polysome aggregates in cytoplasm (arrow). $\times 21,000$

(b) Detail of plasma cell. Numerous Russell bodies in dilated cisternae of rough-surfaced endoplasmic reticulum. $\times 24,000$

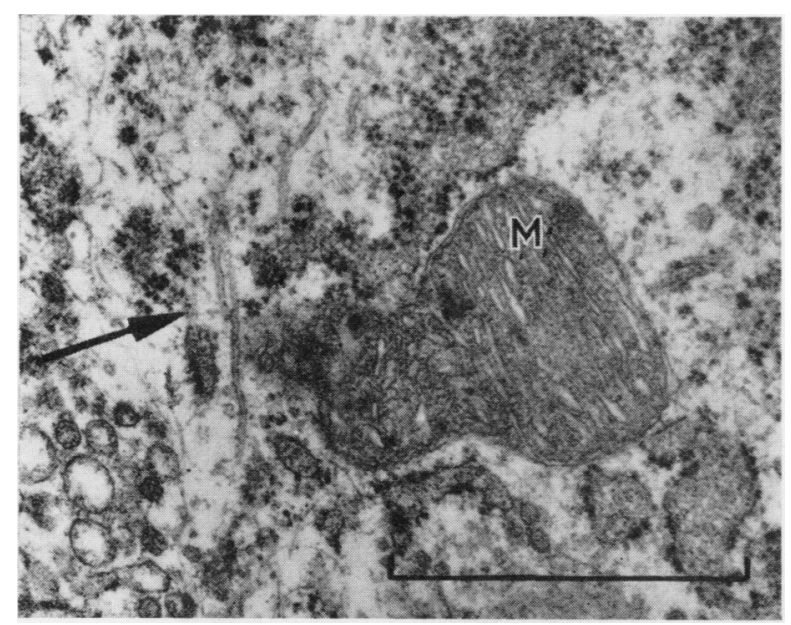

FIG. 3 Linear and rosette-like aggregates of polysomes in cytoplasm of a plasma cell. Arrow shows microtubules. $M=$ mitochondrium. $\times 35,600$

found in the periphery of germinal follicles (Fig. 8).

Lymphocytes, plasma cells, and macrophages were seen in close proximity, the intervening spaces being not more than $200 \AA$. Moreover, loose intercellular bridges were seen between lymphocytes and plasma cells and less frequently between macrophages (Fig. 9). The fibrils forming the intercellular bridges were seen to enter the vacuolar cytoplasmic inclusions close to the cell membrane.

In the cytoplasm and occasionally in the nuclei of macrophages, short helical tubular structures of varying electron density were observed. These structures measured about $120 \AA$ in diameter and $800-1,000 \AA$ in length. They had no limiting mem-

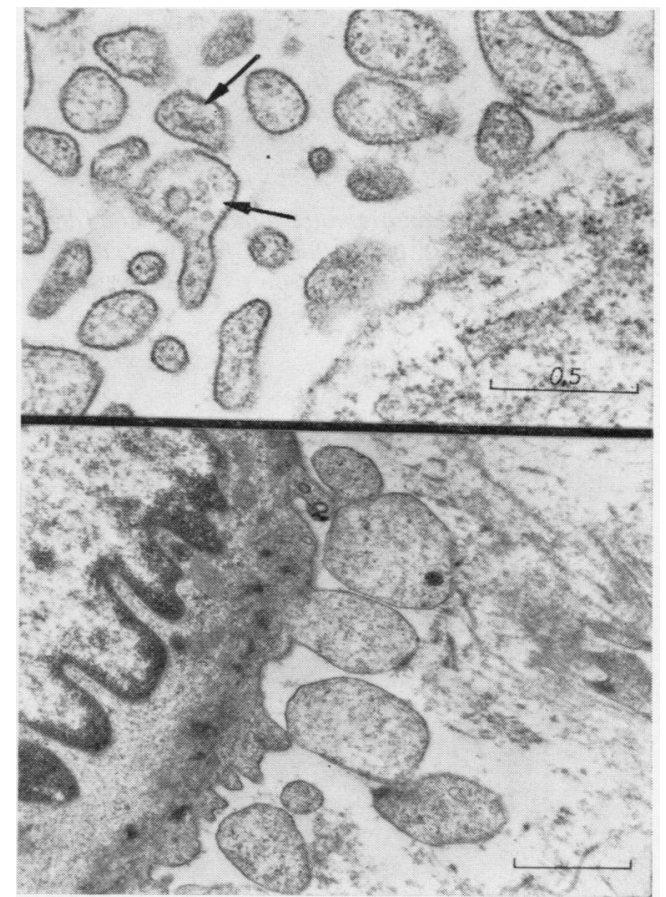

FIG. 4 (a) Cytoplasmic fragments limited by a unit membrane close to surface of a young plasma cell. Vacuoles and tubulofilamentous substance in fragments (arrow). $\times 30,000$

(b) Detaching of similar membrane fragments from a lymphoid cell. $\times 12,000$

brane, and were associated with lysosomes (Fig. 10). They are probably of nuclear origin.

Cytopathic changes were seen in both lymphocytes and plasma cells. 


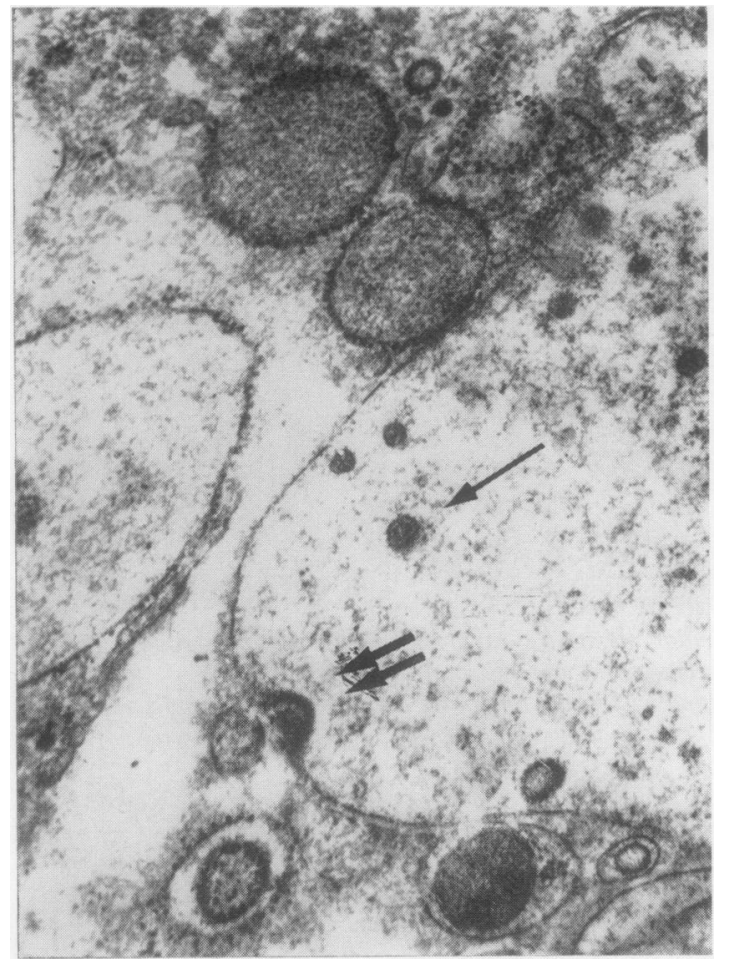

FIG. 5 Particles reminiscent of a mature virion (arrow) in cytoplasmic fragment. On surface of fragment, detachment of 'coated' vacuole (double arrow). Above free vacuoles bearing ribosomes. $\times 35,600$

\section{Discussion}

The formation of germinal follicles in the rheumatoid synovial membrane is usually taken as evidence of an immune response to some antigen (Cottier, Keiser, Odartchenko, Hess, and Stoner, 1967; Cooper, Gabrielsen, Peterson, and Good, 1967; Good, Cooper, Peterson, Hoyer, and Gabrielsen, 1967; Hess and Cottier, 1971 ; Lennert, Caesar, and Müller, 1967).

There is little doubt that the plasma cell is the predominant producer of humoural antibody (Fagraeus, 1948; Leduc, Avrameas, and Bouteille, 1968). However, it has been demonstrated that cells at various stages of development, including cells with only sparse endoplasmic reticulum, may produce antibody (Harris, Hummeler, and Harris, 1966; Micklem and Brown, 1967). The finding of vacuoles rimmed with ribosomes in the cytoplasm of immature cells in the lympho-plasmocyte series as well as the numerous polysome aggregates found in these cell types can therefore be considered as the morphological manifestation of increased protein synthesis. Moreover, it seems that the contents of these vacuoles have found their way into the extracellular space and thence into phagocytic cells. This suggests a possible origin of the intracytoplasmic inclusions found in $\vec{\theta}$ RA cells (Hollander, McCarty, Astorga, and Castro Murillo, 1965; Zucker-Franklin, 1966).

FIG. 6 Virus-like particles budding from plasma membrane of macrophages (arrow). Double arrow shows free virus-like particle in extracellular space. $\times 35,600$

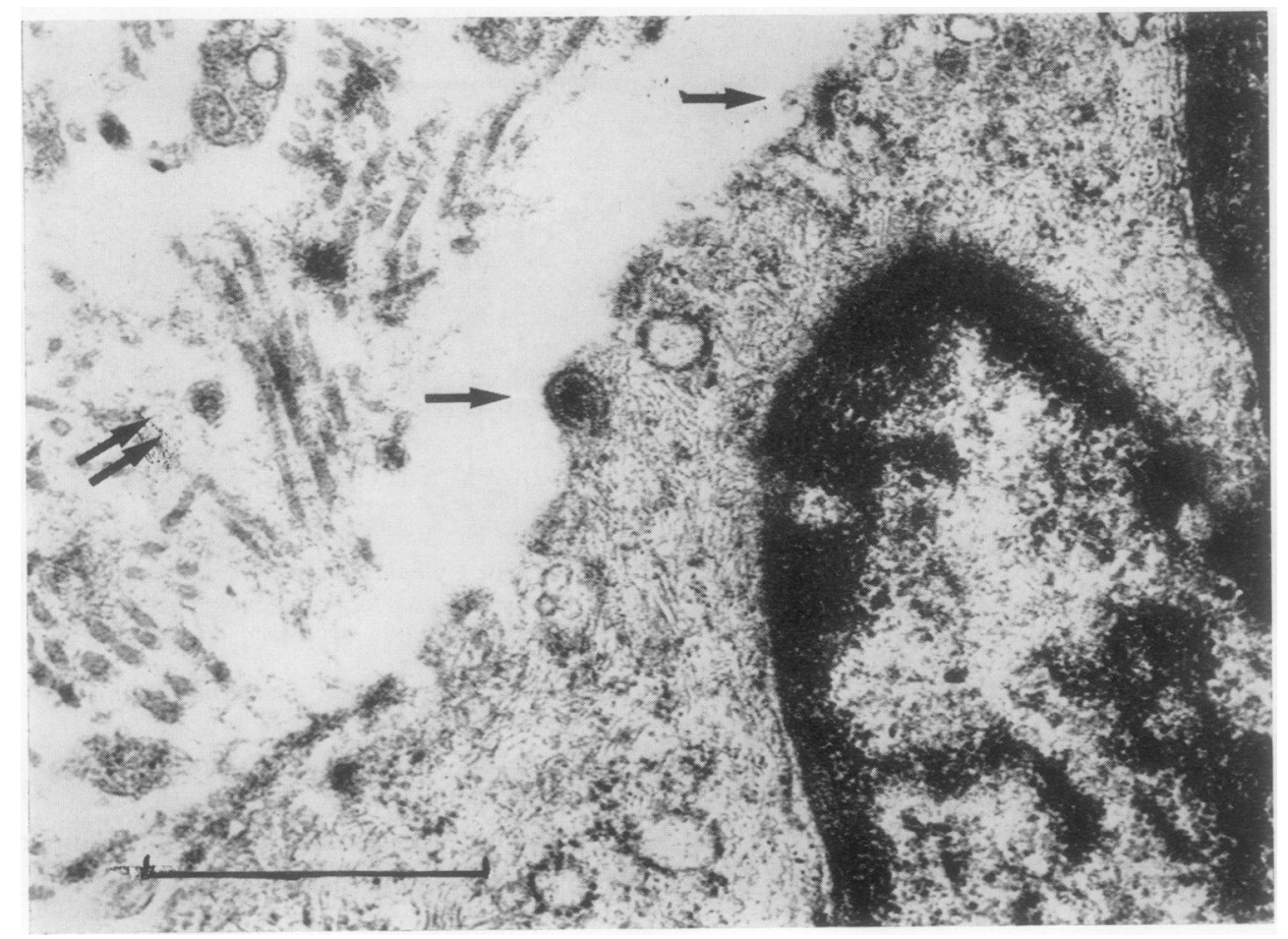




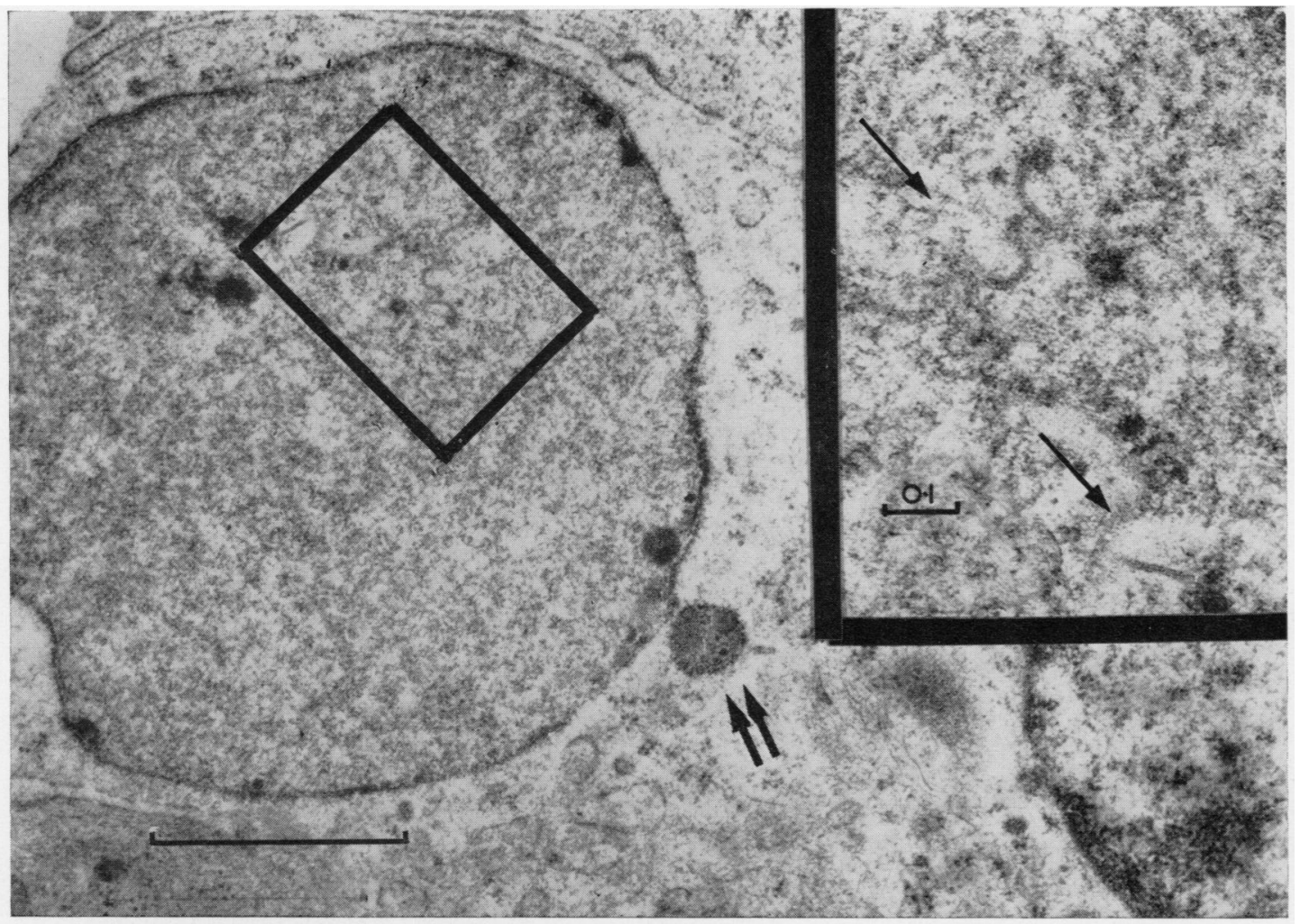

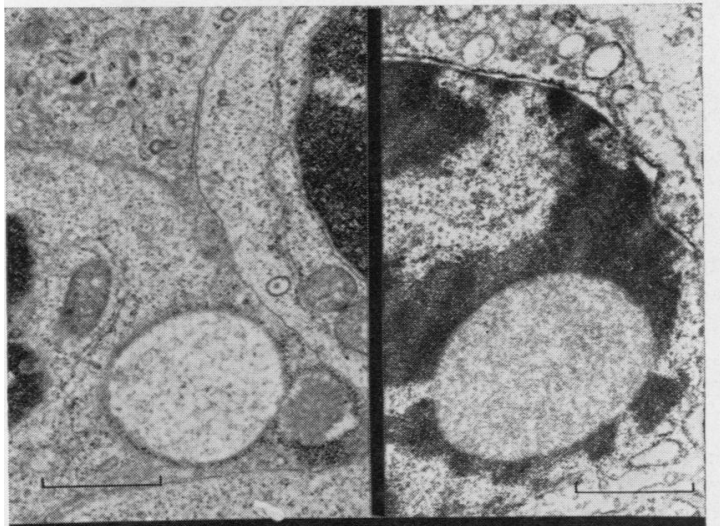

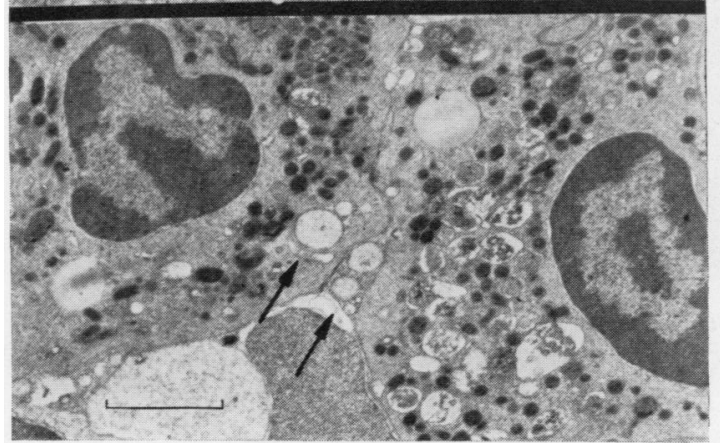

FIG. 7 Nucleocapsid-like tubulofilamentous threads in nucleus of immature lymphoid cell. Double arrow shows crystalloid in cytoplasm. $\times 24,000$

Inset: Nucleocapsid-like structures within framed area. $\times 72,000$

The observed detachment of cytoplasmic fragments of lymphoid elements and their loose connection to the surface of plasma cells may be considered as the morphological sign of transfer of information between cells involved in the immune reaction. The occurrence of loose fibrillar intercellular bridges among the macrophage-lymphocyte-plasma cell population in rheumatoid synovial membrane may also support this assumption.

Short tubular structures about $120 \AA$ in diameter were found in the cytoplasm and nuclei of macrophages. The dimension and shape of these particles are similar to those seen in various collagen diseases (Györkey, Min, Sinkovics, and Györkey, 1969;

FIG. 8 (a) Vacuoles surrounded by ribosomes in cytoplasm of lymphoid cell. $\times 12,000$

(b) Inclusion containing tubulo-filamentous substance of medium electron density connected with caryoplasm. $\times 12,000$

(c) Arrows show ribosome-surrounded vacuoles in cytoplasm of a polymorphonuclear leucocyte and extracellular space. $\times 12,000$ 

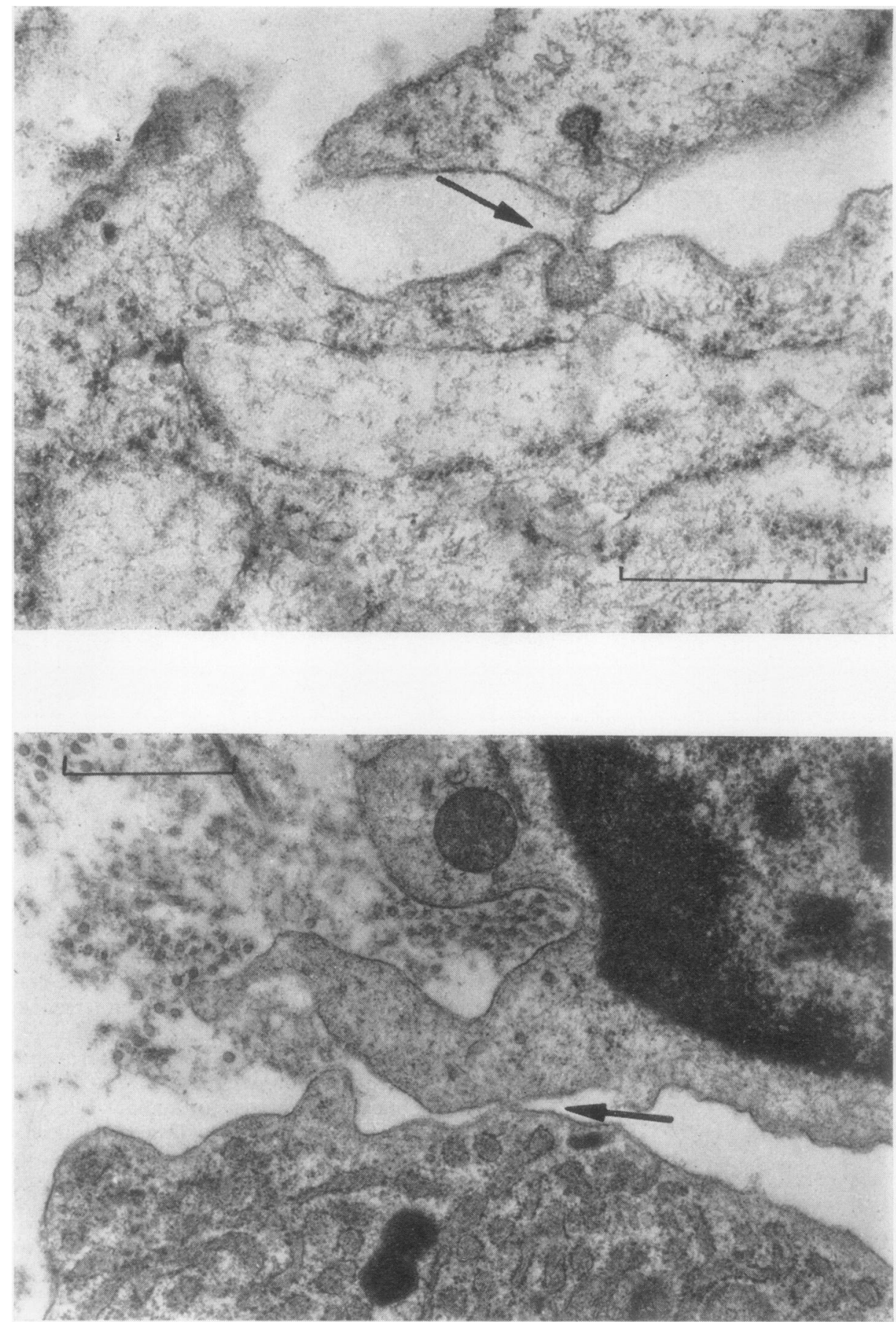

FIG. 9 (a) Intercellular bridge formed between two cells. Coated vesicle at site of bridge (arrow). $\times 35,600$

(b) Intercellular connection formed between cytoplasmic projection of a lymphocyte and a plasma cell (arrow). $\times 24,000$ 


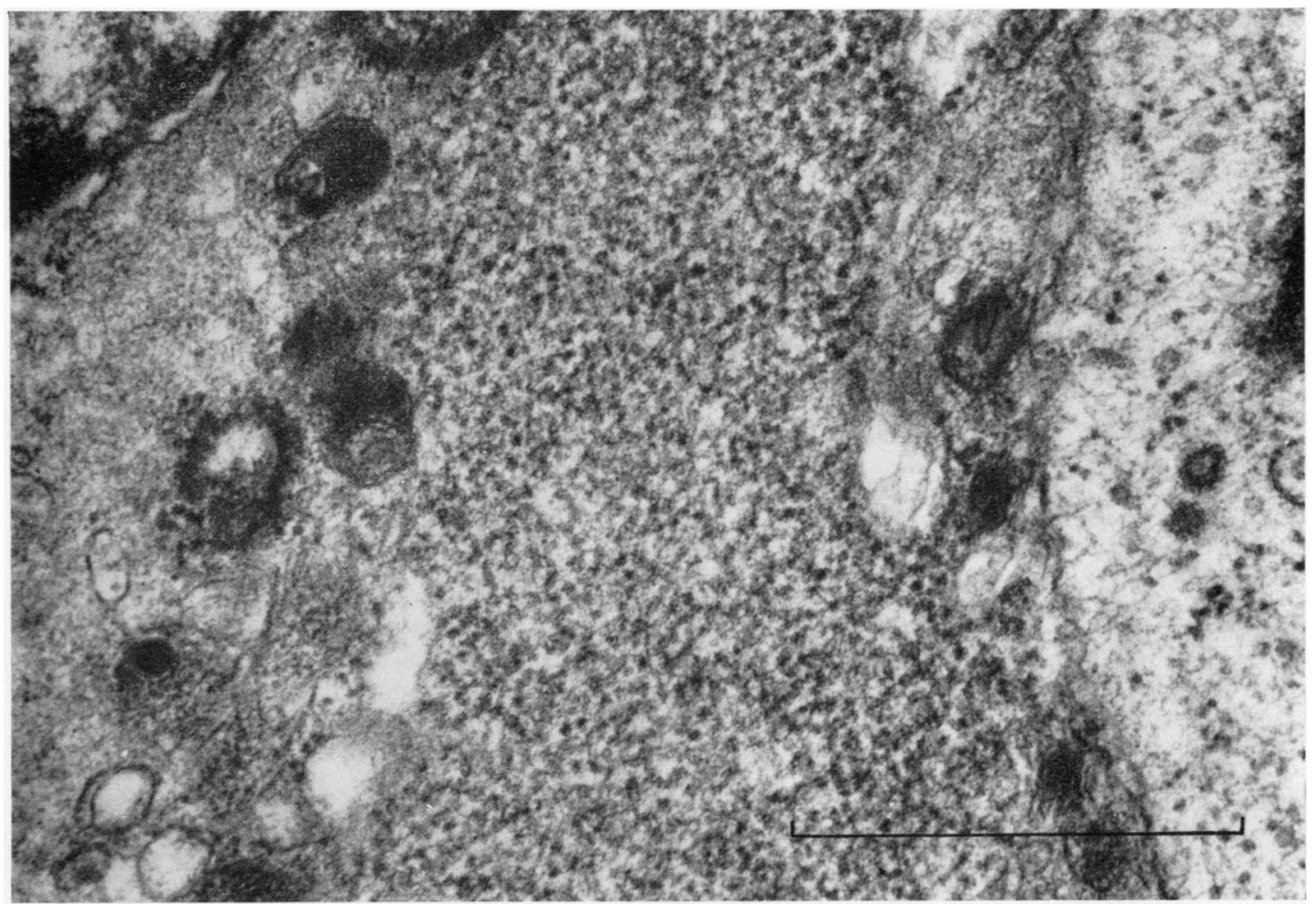

FIG. 10 Detail of macrophage containing short tubular structures. Increased lysosomal activity to be seen around tubules. $\times 45,000$

Sinkovics, Györkey, and Thoma, 1969). They have been thought by some to be nucleoprotein strands of an unidentified myxovirus, but according to Sinkovics, Trujillo, Pienta, and Ahearn (1970), they may be merely degenerative.

Recently, characteristic nuclear bodies, crystalloid formations, and virus-like particles have been demonstrated in rheumatoid synovial membrane (Neumark and Farkas, 1970; Neumark, Hollos, and Farkas, 1973; Neumark, 1972). The flexible threads with tubular structure, about $160 \AA$ in diameter, found in cytoplasmic and nuclear inclusions in lymphocytes and immature plasma cells in this present study are reminiscent of the nucleocapsids of some paramyxovirus (Goffe, 1962; Howatson, 1962; Nakai and Imagawa, 1969; Raine, Feldman, Sheppard, and Bornstein, 1969; Waterson, Cruickshank, Lawrence, and Kanarek, 1961). According to present knowledge, it no longer appears questionable that different kinds of viruses may cause autoimmune diseases, even though this has only as yet been proved in certain animal diseases. Budding of virus from host cell has been demonstrated in rheumatoid synovium. This process may involve incorporation of host cell membrance into the protein envelope of the virion, and the consequent production of new antigenic sites.

The present observations of virus-like structures in germinal follicles supports the view that hostcellvirus complex may be responsible for the immune reaction.

\section{Summary}

Ultrastructural alterations of the cells in germinal follicles in rheumatoid synovial membrane, have been investigated. All cell types belonging to the plasmocyte series were identified. The morphological signs of increased protein synthesis were observed in the cells belonging to the plasmocyte series. Detachment of cytoplasmic fragments from immature lymphocytes and plasma cells was seen. In lymphocytes, cytoplasmic and nuclear inclusions were observed containing tubular filaments about $160 \AA$ in diameter. Loose intercellular bridges were observed among lymphocytes, plasma cells, and macrophages. Short tubular structures $120 \AA$ in diameter, resembling altered nuclear components, were found in the cytoplasm of macrophages. 


\section{References}

Cottier, H., Keiser, G., Odartchenko, H., Hess, M., and Stoner, R. D. (1967) In 'Germinal Centers in Immune Responses', ed. H. Cottier, N. Odartchenko, R. Schindler, and C. C. Congdon, p. 270. Springer, Berlin (De novo formation and rapid growth of germinal centers during secondary antibody responses to tetanus toxoid in mice)

Cooper, M. D., Gabrielsen, A. E., Peterson, R. D. A., ANd Good, R. A. (1967) Idem, p. 28 (Ontogenetic development of the germinal centers and their function: Relationship to the bursa of Fabricius)

Fagraeus, A. (1948) Acta med. scand., 130, Suppl. 204 (Antibody production in relation to the development of plasma cells)

Goffe, A. P. (1962) Amer. J. Dis. Child., 103, 327 (Discussion of papers on measles virus)

Good, R. A., Cooper, M. D., Peterson, R. D. A., Hoyer, J. R., AND Gabrielsen, A. E. (1967) In 'Germinal Centers in Immune Responses', ed. H. Cottier, N. Odartchenko, R. Schindler, and C. C. Congdon, p. 386. Springer, Berlin (Immunological deficiency diseases of man, relationships to disturbances of germinal center formation)

Györkey, F., Min, K. W., Sinkovics, J. G., AND Györkey, P. (1969) New Engl. J. Med., 280, 333 (Systemic lupus erythematosus and myxovirus)

HarRis, T. B., Hummeler, K., AND Harris, S. (1966) J. exp. Med., 123, 161 (Electron microscopic observations on antibody-producing lymph node cells)

Hess, M. W., AND CotTIER, H. (1971) In 'Rheumatoid Arthritis', ed. W. Müller, H. G. Harwerth, and K. Fehr, p. 339. Academic Press, London and New York (The problem of ectopic germinal centre formation, with reference to antibody formation in the synovial membrane)

Hollander, J. L., McCarty, D. J., Astorga, G., and Castro-Murillo, E. (1965) Ann. intern. Med., 62, 271 (Studies on the pathogenesis of rheumatoid joint inflammation, I. The R.A. cell and a working hypothesis)

Howatson, A. F. (1962) Fed. Proc., 21, 947 (Architecture and development of tumor viruses and their relation to viruses in general)

Leduc, E. H., Avrameas, S., AND Bouteille, M. (1968) J. exp. Med., 127, 109 (Ultrastructural localization of antibody in differentiating plasma cells)

LenNert, K., CAESAR, R., AND Müller, H. K. (1967) In 'Germinal Centers in Immune Responses', ed. H. Cottier, N. Odartchenko, R. Schindler, and C. C. Congdon, p. 49. Springer, Berlin (Electron microscopic studies of germinal centers in man)

MiCKLEM, H. S., AND BROWN, J. A. H. (1967) Idem, p. 277 (Germinal centers, allograft sensitivity and isoantibody formation in skin allografted mice)

NAKaI, M., AND ImaGaWA, D. T. (1969) J. Virol., 3, 187 (Electron microscopy of measles virus replication)

NeumarK, T. (1972) Trans. II Int. Congr. Virology, Budapest, 1971, p. 211. Karger, Basel (Possible viral etiology for rheumatoid arthritis)

— AND Farkas, K. (1970) Ann. rheum. Dis., 29, 653 (Nuclear bodies in rheumatoid synovium)

- Hollos, I., AND FARKAS, K. (1973) Scand. J. Rheumatol., 2, 21 (Virus-like particles in rheumatoid synovium)

Raine, C. S., Feldman, L. A., Sheppard, R. D., and Bornstein, M. (1969) J. Virol., 4, 169 (Ultrastructures of measles virus in cultures of hamster cerebellum)

Ropes, M. V., Bennett, G. A., Cobb, S., Jacox, R., and Jessar, R. A. (1959) Ann. rheum. Dis., 18, 49 (Diagnostic criteria for rheumatoid arthritis, 1958 revision)

Sinkovics, J. G., GyörkeY, F., AND ThOMA, G. W. (1969) Texas Rep. Biol. Med., 27, 887 (A rapidly fatal case of systemic lupus erythematosus. Structures resembling viral nucleoprotein strands in the kidney and activities of lymphocytes in culture)

- Trujillo, J. M., Pienta, R. J., And Ahearn, M. J. (1970) In 'Genetic Concepts and Neoplasia' 23rd Symp. Fundamental Cancer Research, Anderson Hospital and Tumor Institute, Houston, Texas, 1969, p. 620. Williams and Wilkins, Baltimore (Leukemogenesis stemming from autoimmune disease)

Waterson, A. P., Cruickshank, J. G., Laurence, G. D., And KanareK, A. D. (1961) Virology, 15, 379 (The nature of measles virus)

ZuCKER-FrankLIN, D. (1966) Arthr. and Rheum., 9, 24 (The phagosomes in rheumatoid synovial fluid leukocytes: a light, fluorescence, and electron microscope study) 